\title{
Evaluation of the insulin administration technique in a tertiary hospital
}

Karla Borges Daniel", Karina Saiuri Takatori, Adriana Russo Fiore, Arnaldo Moura Neto, Elizabeth João Pavin, Walter José Minicucci, Maria Cândida Ribeiro Parisi

From 20th Brazilian Diabetes Society Congress

Porto Alegre, Brazil. 11-18 November 2015

\section{Background}

Optimizing glycemic control is important to minimize the risk of macro and microvascular complications in diabetes. Therefore, it is important that patients under insulin treatment know the correct technique for insulin self-administration to ensure proper management.

\section{Objective}

Assess whether patients with longstanding diabetes followed in a tertiary hospital know how to correct selfadminister their insulin.

\begin{tabular}{|c|c|c|}
\hline Question & YES & NO \\
\hline 1.Do you use insulin for more than 01 year? & $100(100 \%)$ & 0 \\
\hline 2.Do you self-administer the insulin injections? & $100(100 \%)$ & 0 \\
\hline 3.Do you use disposable syringes? & $100(100 \%)$ & 0 \\
\hline 4.Do you have any visual impairment? & $30(30 \%)$ & $70(70 \%)$ \\
\hline $\begin{array}{l}\text { 5.Do you have any motor disorder, like tremors, that } \\
\text { compromises the insulin injection? }\end{array}$ & $6(06 \%)$ & $94(94 \%)$ \\
\hline $\begin{array}{l}\text { 6.Do you have any bone or joint disease that } \\
\text { compromises the insulin injections? }\end{array}$ & $4(04 \%)$ & $96(96 \%)$ \\
\hline $\begin{array}{l}\text { 7.Do you have any neurological disorder that } \\
\text { compromises the insulin injections? }\end{array}$ & $2(02 \%)$ & $98(98 \%)$ \\
\hline $\begin{array}{l}\text { 8. Do you wash your hands before manipulating the } \\
\text { insulin? }\end{array}$ & $91(91 \%)$ & $9(9 \%)$ \\
\hline $\begin{array}{l}\text { 9. Do you observe the insulin physical characteristics } \\
\text { before injection? }\end{array}$ & $88(88 \%)$ & $12(12 \%)$ \\
\hline $\begin{array}{l}\text { 10.Do you homogenize the insulin without shaking } \\
\text { it? }\end{array}$ & $70(70 \%)$ & $30(30 \%)$ \\
\hline 11.Do you clean the rubber tip with alcohol $70 \% ?$ & $58(58 \%)$ & $42(42 \%)$ \\
\hline $\begin{array}{l}\text { 12. Do you take out the air bubbles inside the syringe } \\
\text { before injection? }\end{array}$ & $88(88 \%)$ & $12(12 \%)$ \\
\hline 13.Do you administer the correct insulin dose? & $89(89 \%)$ & $11(11 \%)$ \\
\hline $\begin{array}{l}\text { 14.Do you clean the skin with alcohol } 70 \% \text { before } \\
\text { injections? }\end{array}$ & $65(65 \%)$ & $35(35 \%)$ \\
\hline 15.Do you correctly do the skin fold for injections? & $71(71 \%)$ & $29(29 \%)$ \\
\hline $\begin{array}{l}\text { 16. Do you introduce the needle at an angle of } 90 \\
\text { degrees? }\end{array}$ & $89(89 \%)$ & $11(11 \%)$ \\
\hline $\begin{array}{l}\text { 17.Do you wait for } 5 \text { seconds before removing the } \\
\text { needle from the skin? }\end{array}$ & $47(47 \%)$ & $53(53 \%)$ \\
\hline $\begin{array}{l}\text { 18.Do you pinch the skin without massaging when } \\
\text { you remove the needle? }\end{array}$ & $46(46 \%)$ & $54(54 \%)$ \\
\hline 19. Do you rotate between insulin application sites? & $89(89 \%)$ & $11(11 \%)$ \\
\hline $\begin{array}{l}\text { 20.Have you anytime injected the insulin through } \\
\text { your clothes? }\end{array}$ & $05(05 \%)$ & $95(95 \%)$ \\
\hline
\end{tabular}

${ }^{*}$ Highlighted the inadequate answers

Figure 1 Results of the questionnaire.

\footnotetext{
* Correspondence: ka_borgesdaniel@hotmail.com
}

UNICAMP, Campinas, Brazil 


\section{Materials and methods}

Cross sectional study consisting on the application of a questionnaire about the procedures of insulin selfadministration to 100 patients treated at a tertiary type 2 diabetes mellitus unit. The questions assessed time of diabetes, types of insulin used, total insulin dose, comorbidities and use of other drugs. There were also specific questions about the technique of insulin self-administration according to guidelines of the Brazilian Diabetes Society.

\section{Results}

Of 100 patients evaluated, $50 \%$ were female, mean age 61.54 yrs. (range $35-86$ yrs.). The mean disease duration was 18,52 yrs. $(2-40$ yrs.). Most patients learned how to apply insulin with a nurse (48\%), 17\% were instructed by a doctor and $27 \%$ could not remember. All but 2 patients used drugs other than insulin. As for type of insulin, 80 patients $(80 \%)$ used human insulin, most of them (61\%) three injections a day and $76 \%$ mixed the two types of insulin in the same syringe. The $100 \mathrm{cc}, 50 \mathrm{cc}$ and $30 \mathrm{cc}$ syringes were used by $59 \%, 27 \%$ and $5 \%$ of patients, respectively, reflecting the greater distribution of $100 \mathrm{cc}$ syringes by basic health units. The mean total insulin dose was 77.72 IU (8-212 IU). Regarding the 20 specific questions on insulin administration technique, the mean number of correct answers was $9.87(6-13)$.

\section{Conclusion}

This study shows that even in a tertiary hospital there is a high rate of mistakes in insulin self-administration, which may be associated with poor glycemic control and an increased incidence of diabetes complications, including hypoglycemia. Thus, it is important that all health care professional actively inquire how the patients routinely administer their insulin, since diabetes is a chronic disease that requires a continuous educational process

\section{Submit your next manuscript to BioMed Central} and take full advantage of:

- Convenient online submission

- Thorough peer review

- No space constraints or color figure charges

- Immediate publication on acceptance

- Inclusion in PubMed, CAS, Scopus and Google Scholar

- Research which is freely available for redistribution 